Assurances et gestion des risques

Insurance and Risk Management

\title{
Note au sujet d'un article paru en 2016
}

Volume 86, numéro 1-2, juin 2019

URI : https://id.erudit.org/iderudit/1062469ar

DOI : https://doi.org/10.7202/1062469ar

Aller au sommaire du numéro

\section{Éditeur(s)}

Faculté des sciences de l'administration, Université Laval

\section{ISSN}

1705-7299 (imprimé)

2371-4913 (numérique)

Découvrir la revue

Citer ce document

(2019). Note au sujet d'un article paru en 2016. Assurances et gestion des risques / Insurance and Risk Management, 86(1-2), 125-125.

https://doi.org/10.7202/1062469ar

Tous droits réservés (C) Faculté des sciences de l'administration, Université Laval, 2019
Ce document est protégé par la loi sur le droit d'auteur. L’utilisation des services d'Érudit (y compris la reproduction) est assujettie à sa politique d'utilisation que vous pouvez consulter en ligne.

https://apropos.erudit.org/fr/usagers/politique-dutilisation/ 


\section{NOTE AU SUJET D’UN ARTICLE PARU EN 2016}

Le volume 83 , numéros 1-2, publié en première moitié de 2016, contenait un article intitulé "Étude de ruine d'une compagnie d'assurance automobile", dont l'auteur présumé était Mohamed Dakkon. Cet article était en fait une copie intégrale d'un document de travail intitulé "Calcul de la probabilité de ruine» et co-écrit par Lyda Tlilane, Hanane Allaoua, Zina Benouaret et Djamil Aissani. Le document de travail de

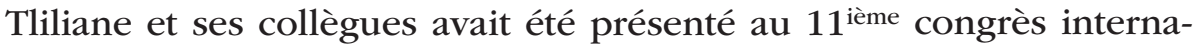
tional de génie industriel (CIGI 2015) à Québec entre le 26 et le 28 octobre 2015 . Nous présentons toutes nos excuses aux auteurs pour cet imbrolgio. 